\title{
Death By Crucifixion: View of The Medicolegal Expert
}

\author{
Tumanov Eduard ${ }^{1}$, Ali Ali Al-Turki ${ }^{2 *}$ and Tetyuev Andrey ${ }^{3}$ \\ ${ }^{1}$ Institute of advanced Training and Retraining of the State Service of Medico-Legal Examinations, Belarus \\ ${ }^{2}$ Department of Forensic Medicine, Sana'a University, Yemen \\ ${ }^{3}$ Vitebsk State Medical University, Belarus
}

Submission: February 19, 2017; Published: March 22, 2017

*Corresponding author: Ali Ali Al-Turki, Department of Forensic Toxicology, Sana’a University, Al-Alsbahi Area, Yemen, Tel: +967 $738976167 ;+967$ 770876 790; Email: prof.aliturki@gmail.com

Abstract

The paper considers historical evidences of the execution by crucifixion.The modern medical theories explaining death of Jesus Christ are analysed.It is noticed, that none of existing theories cannot interpret comprehensively all circumstances of the execution described in the Gospels. By authors' opinion cause of Jesus Christ death at the crucifixion was a disseminated intravascular coagulation.

\section{Introduction}

Being a corner stone of the New testament and Christian religion, the evangelical narration about Jesus Christ crucifixion had been drawing attention of many millions people, both Christians and representatives of other religions and convictions, almost for two thousand years.If in the last centuries the crucifixion was considered mainly from theological and historical positions, the XX century was marked by surge of medical and biological researches devoted to investigation of thanatogenesis of the crucifixion. However the careful analysis of the suggested concepts of death at the crucifixion shows that not all of them are well-founded. Moreover, some authors sometimes do not consider available historic facts.Not only the analysis of the original Greek text of the Gospel is absent in the published works but authors ignore the Gospel itself at times.

Certainly, all that facts affects both the made researches quality and the drawn conclusions adequacy. At the same time it is obvious that the reliable theory explaining physical death of Jesus Christ can be proposed only in full conformity with Gospel texts, should consider as much as possible historical and archaeological data and must be based on fundamental medical knowledge. It is considered that the crucifixion as a way of execution have been invented by Babylonians not wishing to profane the earth devoted to Ahuramazda by dead bodies of executed criminals. References about this we can meet in the extant Herodotus as well as other antique authors' works (III, 132; 159; IV, 43; VI, 30; VII, 194).

After a gain of Persia by Alexander the Great in IV century BC this mode of punishment was extended through all subjugated territories and was used in Greece, Middle East countries, Egypt and Phoenicia. Romans have adopted the crucifixion from their worst enemies Carthaginians which used the execution often enough (Valerius Maximus II, 7; Silius Italicus II, 334, Polybios I, 24). In the ancient world it was extremely negative posotion to the execution by means of crucifixion. Greeks considered such execution as extremely humiliating and unworthy, Jews considered all hung up on a cross as damned. Romans perceived the crucifixion as shameful execution, punishment for slaves (Tacitus. History IV, 11; Juvenal. Satires. VI, 219). Greek law in due time and later Roman one forbade crucifixion of free citizens. However the crucifixion was widely applied in the Roman republic for punishment of slaves, deserters and the state criminals. Thus on Pompey's order 6000 risen slaves were crucified along the Appian Way after Spartacus defeat. After transformation of Rome into the empire covered all Mediterranean the crucifixion as an effective intimidation remedy was applied by Romans to inhabitants of the subdued provinces. While calling the crucifixion «the most painful of deaths» Joseph Flavian (Judaic war VII, 6, 4) notice the considerable number of such executions performed by Romans in Palestine especially during revolt in the 66-70th DC (Antiquities 17, 10; 20, 6; Judaic war. II, 12, 6; 13, 2; 14, 9; III, 7, 33; V, 11, 1; VII, 10, 1).

Initially procedure of execution was not regulated accurately. A person condemned for the crucifixion was simply tied to a tree or to upright dug wooden column in such a manner that feet of the condemned did not touch the ground. However to cause the maximum pain to condemned person and to prolong his sufferings Romans not only considerably refined technique of 
the crucifixion but also regulated the procedure in detailed. The common form of a sentence of death on the cross was verbalized by judge as: «ibis ad (or in) crucem» - « You shall go to the cross!» Then condemned person was put to the flagellation. To this end he was disrobed and tired to a column by hands in court territory. Then he was flogged with the short lash named flagrum (or flagellum). The lash consisted of a handle and leather belts of different length. Ends of the belts were blumbed and jagged fragments of bones were twisted trough the length. Romans did not restrict number of the blows while under the Jewish laws it was not allowed to put more than forty lashes during flagellation. Therefore Pharisees watching flagellation limited number of blows to thirty nine for avoiding the law violation if they are mistaken in the counting. Romans flouted the Judaic laws and could not adhere to the exact number of blows. Blows with flagrum were administered by one or two executors (lictors) to a back, buttocks and hips of the condemned person. Only blows to the heart area were avoided because of possibility of the premature death. Consequences of such flagellation were really terrifying. In sites of blows with flagrum's belts the skin was torn and underlying soft tissues were crushed. It is no coincidences that lash for punishments sometimes also named flagrum taxillatum - "caustic lash, ghastly scourge".

At the same time flagellation while causing extensive damages of the soft tissues of the back could not cause considerable blood loss since it not led to damage of the major blood vessels. Bleeding from blood vessels of the skin and subcutaneous tissue damaged at execution was rather insignificant and stopped soon enough. After flagellation condemned person was dressed and forced to bear a cross on his shoulders to an execution place that was the great humiliation over doomed, his natural love for a life and hatred for the tool of the death [1-4]. The cross was made in advance and used for execution many times. It consisted of two basic parts - a horizontal beam (patibulum) and a vertical part (staticulum). According to available archaeological and historical data the weight of whole assembled cross could reach $136 \mathrm{~kg}$ and more. To bear such load was extremely hard even for a healthy person but for person just flagellated it was beyond his power. Thereof convict sometimes bore not whole cross but only patibulum which weight was (according to different sources) from 34 to $57 \mathrm{~kg}[1,2,5]$. Likewise the Christ exhausted after flagellation could bear his cross hardly. Therefor "As they led him away, they seized Simon from Cyrene, who was on his way in from the country, and put the cross on him and made him carry it behind Jesus" (Luke 23:26).

After a cross or its parts have been fixed on a convict's back he in last procession to the execution place was accompanying by armed security forces from detachment of the Roman soldiers under the command of a centurion. One of soldiers went in advance and bore the plate (titulus) with the name of condemned and his crime. Since this minute guard did not leave the convict until completely was sure that he died. For the crucifixion Romans used different types of tools among which the most common were crux simplex (a simple column without a crossbeam), crux commissa (a cross tied in the form of the letter «T»), crux immissa (a cross knocked together in the form of a symbol «†») and crux decussata (a cross in the form of the letter «X»). However there is every reason to believe the Jesus Christ has been crucified on a four-point cross (crux immissa). Extremely valuable, decision evidence in this question is the remark of the evangelist Matthew: "And over his head they put the charge against him, which read, «This is Jesus the King of the Jews»" (Matthew. 27:37). The evangelist speaks here about the plate on which the imaginary fault of the Savior has been designated. But it is quite obvious that to place such plate over the head of the Christ the basic vertical column was to continue over a cross bar. Thus the cross was to be four-point instead of three-point (in the form of the letter T) or knocked together in the form of the letter X. In the works of the antique writers (Tertullian, Origenist etc.) and in some archaeological evidences (coins, monograms, old-Christian images) there are indications of a three-point Christ's Cross.

However this only indicates that the early Christian Church has not at once solved a question concerning the shape of that sacred tree of the Cross on which Jesus Christ was crucified. The disagreement in this case seems more naturally and more clearly considering the Christianity was accepted by the same Romans who knew several shapes of a cross. On arriving to the place of the crucifixion convict was undressed naked and his clothes was gave to the soldiers guarding a cross. However in Judea Romans meeting Jews' religious views (Genesis 9:22-23; Leviticus 18:6-19; 20:17; Hosea 2:3) left convicts a loincloth (Mishnah [Sanhedrin 6:3]; Tosephta [Sanhedrin 9:6]). Then the convict was placed on a cross. The manner of fixing of the body could varied. According to one of the ways convict was laid on his back with the hands stretched along the patibulum. Then he was nailed with forged four-sided nails of 13-18 centimeters at length and about $1 \mathrm{~cm}$ in a diameter or roped [5]. Then patibulum with the nailed person was lifted by means of a special pitchfork (furcilla) and placed on vertical column in advance dug into the ground (Cicero. In C Verrem. 5:66; Joseph Flavius. Judaic war VII. 6:4). Then the convict's legs were slightly bent in knees and nailed or roped to staticulum. The convicts might also be crucified both on the preassembled crosses laying on the ground and then lifting vertically and on the dug crosses.

To lift the convict on the dug cross and to nail him some efforts were required. Ladders were set against the patibulum. Two soldiers climbed up the ladders and lifted the convict by means of ropes. Soldiers remaining below helped them. Crucified convict lifted up to the appropriate height was roped to the patibulum, then two nails were put on his wrists and hammered in wood. At this time the soldiers standing below was roping convict's legs to the staticulum. For this one foot covered another one and a nail was hammered through the both feet. 
Each foot might be nailed separately. How the Jesus Christ's feet have been nailed, with one or two nails, it is not known exactly. Some Fathers of Christian Church (St. Gregory Nazianzen the Elder, Egyptian bishop Nonn) pointed out the one nail but others (St. Gregory of Tours, St. Cyprian) said about four nails, two for hands and two for feet. Iconography of the Orthodox Church has accepted the second legend but the Roman Catholic Church the first one. To keep the crucified person alive as much is possible on the cross and to prolong victim's torments, Romans applied different devices provided some support for a victim's body (this can explain a phrase «to sit on a cross» used by Romans). For this purpose the small ledge or seat (sedile) was placed on the staticilum between the legs of the convict. To increase sufferings of the victim the seat was made pointed sometimes. Sometimes instead of the seat support for feet was made as a plank (pedale or suppedaneum) nailed in the bottom of the staticulum.

It was less painful thanthe being on the pointed seatbut also prolonged sufferings of the convict. In both these cases the crucified person rather sat or stood on the cross being nailed to it than hang on the cross. Traditional Christian iconography and painting represent Crucified Christ with the hands nailed in the middle of palms. However the researches performed by Pierre Barbet, the chief surgeon of St. Joseph's hospital (Paris), in the first half of XX century have shown the Christian artists were off the mark in this respect. Having spent a number of experiments with the amputated hands and with corpses P. Barbet has found out the facts unexpected for that time. As it turned out the hands nailed at level of their middle tore down from nails at loading about $39 \mathrm{~kg}$ (88 pounds). Experimental data have supported the mathematical calculations suggested that the body invariably falls from the cross if the arms of the crucified person abducted from the trunk under an angle close to $68^{\circ}$. Searching for an anatomic place which from the one hand could corresponds to the Evangelical text and historical chronicles as much as possible and from another hand could held reliably the convict on the nails P. Barbet has come to conclusion that Destot space is most suitable for this $[1,2]$. If the nail was hammered between trihedral, capitate and hamate bones, hands of the crucified was reliably held on the cross regardless the body weight. The important to note the fact that the bleeding is relatively minor when the nail penetrates the Destot space as no large blood vessels are damaged.

It is necessary to make a special note that overall the P. Barbet's anatomic data revealed by concerning the fixing of a body on the cross correspond to the New Covenant. The ancient Greek word $\chi \varepsilon\llcorner\rho$ used in the Evangel according to St John meant

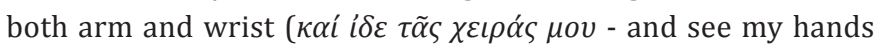
(John 20:27) ( $\chi \varepsilon \iota \rho \alpha ́$ s ad verbum means wounds on hands, wrists). The divergence of P. Barbet's data and traditional iconography may be explained by the fact that since IV AD after Constantine the Great's edict execution by crucifixion has been forbidden in the Christian world and many knowledge of this procedure was forgotten. The first scientific works devoted to studying of the mechanism of death at the crucifixion were executed by the French physician A. LeBec in 20th years of the XX century. He was the first who made a suggestion that the death at the crucifixion came owing to asphyxia [6]. The suggestion was supported by many scientists and now it is accepted as a main cause of death at the crucifixion being considered as a variant of the postural asphyxia $[3,7,8]$. The classical experiments of $\mathrm{P}$. Barbet convincingly shown that in case of the crucifixion on the cross when the arms were little bent in elbows and stretched along the patibulum, legs were semibent in knee joints and feet were fixed to staticulum the person on the cross could take only two basic positions. The first one is with the feet unbent in knees and the arms stretched along the patibulum (the straightened position after P. Barbet).

Convict thus leant on the feet which in this position took the weight almost of the whole body. The second position is with the legs bent in the knee joints. In this case the trunk sagged downwards and somewhat forward, and arms were stretched upwards to the patibulum and aside under the angle of 60-65. In such position convict's wrists were to bear all weight of the body. As the muscular weariness increased the convict spend more and more time in the second position. Overdistension of the chest under the weight of the body led quickly enough to increase of weariness of the intercostal muscles and diaphragm which are responsible for the breathing. In these conditions it is possible to take breath but the expiration is extremely complicated leading to accumulation of carbon dioxide and other metabolic products. The crucified person could compensate this condition only having taken the first position. To do this it was necessary to straighten legs in knee joints and move the body upwards on a cross. However convict's wrists, arms and humeral joints were under the considerable loading of his own body weight which gradually led to displacement of the shoulder girdle joints. As the weariness developed the convict's arms were more and more in the position when they were directed backward and upward. However the trunk hang forward and downwards on the legs bent in knees thus complicating function of the supplementary respiratory muscles. In addition, each attempt to change position on the cross led the turning of the wrist and leg bones on the nails which together with scratching of the soft tissues by the srabilum caused the strongest pain for the convict.

As for speaking the person should held enough breath, the convict had to rise on the cross for pronouncing each word. To do this he was to lean on the nailed legs and simultaneously pull himself up on the nailed hands scraping the periosteum. It is possible to conceive how painful was each word said by convict on the cross. The more time passed from the crucifixion the more executed person became failing. Spasms and muscular pain increased, dislocation of the shoulder girdle joints became more and more expressed, thus the convict more often took the position interfering normal breathing. The breath was carried 
out only by diaphragm that gradually led to development of the expressed asphyxia which finally caused the death. Such condition was lasting for many racking hours. The Roman historian Origen wrote that he saw the crucified which has been living all night and the next day. The example when three crucified Jews had been remaining alive on a cross within three days we can found in Joseph Flavius's works (Flavius Josephus, Antiquities of the Jews, XIV). During the multiply executions which had followed the Spartacus revolt some of the crucified insurgents communicated with soldiers within three days (Appian. B.Civ. I, 20). A custom of "Crurifragium" (skelokopia) applied to shorten the torture time on the cross when the decision to accelerate approach of death was made.

The skelocopia consisted in the breaking of the crus bones by hammer. The body lost a point of a supporting point and hung on the hands. These conditions quickly caused overdistension of the thorax and asphyxia occurred much faster (in several tens of minutes and even faster). This position was convincingly proved by K-S. D. Schulte. In a number of controlled experiments with volunteers he showed that in cases of crucifixion only by suspension on the hands without supporting on feet all subjects experienced $70 \%$ decreasing of the inspired air volume with failing of arterial pressure by 50\% from normal and twice increasing of the hart rate as soon as the 6th minute. After the 12 minutes breathing was carried out only at the expense of diaphragm movements and subjects became unconscious. If the volunteers were allowed at the crucifixion to lean against feet periodically (once within 20 seconds) there was an expressed normalization of cardiovascular activity and breathing. In the latter case experiment lasted up to 30-40 minutes, then participants became felt expressed pain in wrists and experiment was stopped [9]. The P. Barbet's theory about death at the crucifixion as a result of positional asphyxia caused by position of the body on a cross is seemed to be rather convincing and now it is accepted practically by all researchers. However doing justice to pioneer works of P. Barbet one nevertheless should acknowledge that having discovered features of the approach of death at the crucifixion he could not explain adequately one individual case of Jesus Christ death on a cross.

Indeed, the asphyxiation itself and in particular caused by inability to make an adequate expiration disables not only pronunciation of any words but articulate sounds. However being crucified Jesus Christ could speak quite distinctly up to last seconds of his terrestrial life. This fact is spoken in all four Gospels. Thus in the Gospel According to St. Luke it is told: "Then Jesus, crying with a loud voice, said, «Father, into thy hands I commit my spirit!»And having said this he breathed his last" (Luke, 23:46). The following and important enough objection against the asphyxiation as a cause of Jesus Christ death is time of his stay on the cross. The crucified might stay on the crosses during some days before death but the Christ has died in 3 hours after being nailed to the cross. This is written in the Gospel clear enough. "And it was the third hour, when they crucified him"
(Mark, 15:25) and "It was now about the sixth hour, and there was darkness over the whole land until the ninth hour, while the sun's light failed; and the curtain of the temple was torn in two. Then Jesus, crying with a loud voice, said, "Father, into thy hands I commit my spirit!"And having said this he breathed his last" (Luke 23:44-46).

Pharisees watching the crucifixion did not expect so rapid death of the Christ. While demanding execution in the morning they understood that the convicts would stay on the crosses day of more. That meant the Old Testament Easter which should begin on Saturday may be saddened by execution that was a gross infringement of the Judaic law. On the other hand they were afraid that if the court and execution would be postponed for the days after the Easter Pilate may change his mind and cancel execution. Thus they have maneuvered themselves in a trap. They were afraid to put off the execution but to insult the Easter by death penalty meant not simply to break but seriously insult the law. Thus they have been compelled to ask Pilate's permission about clemency to convicts that is to break crura that would accelerate their death and would allow to remove bodies from crosses prior to the beginning of Old Testament Easter. "Since it was the day of Preparation, in order to prevent the bodies from remaining on the cross on the sabbath (for that sabbath was a high day), the Jews asked Pilate that their legs might be broken, and that they might be taken away" (John, 19: 31). Pilate allowed that. Then soldiers came and broke crura to robbers. But when they came to Jesus Christ they saw He had died and therefore skelocopia against Him was not applied as it was not necessary. In the Evangelical text this fact is paid special attention. "So the soldiers came and broke the legs of the first, and of the other who had been crucified with him; but when they came to Jesus and saw that he was already dead, they did not break his legs" (John. 19:32 -33). Then one of the Roman soldiers wishing to make shure that the Christ has died speared a body.

"But one of the soldiers pierced his side with a spear, and at once there came out blood and water.He who saw it has borne witness - his testimony is true, and he knows that he tells the truth - that you also may believe (John 19:34-35). People of the ancient world and especially soldiers constantly saw violence in their life and could detect does the blood flow out from a live or a dead body. Discharging the blood and water from the Christ's wound has quite assured both the Roman soldiers and Jews about the physical death of the Christ. Of note the fast Christ death surprised not only presents but also Pilate whohas seen much in his lifetime. "Joseph of Arimathe'a, a respected member of the council, who was also himself looking for the kingdom of God, took courage and went to Pilate, and asked for the body of Jesus.And Pilate wondered if he were already dead; and summoning the centurion, he asked him whether he was already dead.And when he learned from the centurion that he was dead, he granted the body to Joseph (Mark 15:43-45). The circumstances of Jesus Christ death noted in the Gospels, particularly rather fast approach of death, Jesus Christ ability to 
clear pronouncing of words up to last minutes of his live, lucidity up to death, and the blood and water stream flowed of the wound inflicted postmortem by a spear, raise doubts about validity of the asphyxial genesis of the Christ death. It has stimulated many researchers to search other, distinct from asphyxial, theories which could explain His terrestrial death. Thus in 1949 The Hibbert Journal have published the R. Primrose's article «A Surgeon looks at the crucifixion» where author asserted that Jesus Christ death on the cross was suspected and a lethal outcome has been resulted from the blow by the spear [10].

In support the opinion the author stated that blood clots are formed in the postmortal period thus it does impossible blood and water effusion from the wound. At present fallaciousness of such "proof" is so obvious that it would be possible even not to consider this version in this article if it was not used by numerous critics of Christianity to this day. Also assumptions have been come out that the fast approach of death was caused by the fatal cardiac arrhythmia resulted from the physical torments at the crucifixion, progressing acidosis [11], pulmonary embolism [1,12-14]. But even the superficial analysis of these and others similar versions shows that they can explain only rate of death leaving undisclosed other circumstances, for example the blood and water effluence from the wound inflicted by a spear. Israeli professor B. Brenner [1] grounding the assumption about thromboembolism as a possible cause of Christ death has advanced a thesis that the most probable source of the thrombi were deep veins of the legs. According to this version pulmonary embolism could be promoted by preceding damage of veins (for example, as a result of the thrombophlebitis) or by the hypercoagulation of the blood caused as a result of castigation, dehydration and prolonged immobilization occurred during the crucifixion. As an indirect confirmation of the hypothesis B. Brenner suggests that Jesus was born in Israel in the Jewish family and consequently might well inherit mutation of the blood coagulation factor $\mathrm{V}$ gene (the factor of Leiden).

Such mutation is widespread among Jews living in Galilee and leads to increasing thrombi formation (resistance to the activated protein C). The argument does not stand up to criticism both from the theological point of view and from the medical one. Actually, it is extremely incorrect to extrapolate the data received from the study of the present-day Galilee population on people occupied this area two thousand years ago. It is obvious that the population gene pool has substantially changed at two thousand years. On the other hand if any inhabitant in the beginning of the first millenium AD had inclination to thrombophilia it would inevitably be manifested by thirty three years of live. A number of other researchers stated the hypothesis, that Jesus Christ death has come as a result of the cardiac rupture with leakage of the pericardial liquid through the wound [15-18]. However this hypothesis has one serious lack. Development of myomalacia which in some cases can complicate a myocardial infarction requires the time considerably exceeding time of Jesus stay on the cross [19]. In addition, blood which would flow out through the broken cardiac wall into the pericardium cavity inevitably would mix up with a relatively small volume (about $30 \mathrm{ml}$ ) of the pericardial fluid and would make impossible formation of two separate flows of blood and water. It is necessary to add that even at assumption about development of the extensive myocardial infarction with swift miomalation followed by cardiac tamponade, this inevitably would lead to cardiogenic shock having enough specific clinical symptomatology.

However there are no indications in Evangelical texts which would allow similar assumption. In 2009 Swedish researcher E. Omerovic has put forward the version that Christ died due to the rupture of myocardium caused by stress-induced cardiomyopathy (Takotsubo cardiomyopathy) clinically and electrocardiographically resembling acute coronary syndrome and characterized by transitional dysfunction of the left ventricle in reply to physical or psychic stress [20]. It is doubtful whether such assumption completely reasonable. Besides already mentioned objections against the version about cardiac rupture, in this case it is necessary to notice that stress-induced cardiomyopathy is mainly described among postclimacteric women without signs of coronary heart diseaseand characterized by rather favorable prognosis [21]. Trying to explain water effusion from the wound inflicted by a spear of the Roman soldier another theory suggests that castigation and the crucifixion has caused rapid development of the posttraumatic exudative pericarditis with cardiac tamponade and approach of fatal outcome. The effused water is nothing more than pericardial fluid flowed out from the cavity damaged by a spear $[8,18]$. However posttraumatic exudative pericarditis does not developed immediately even after significant damage (myocardium trauma, cardiac rupture) Time for its development takes hours and accompanied by well-known clinical picture (dysphagia, cough, dyspnea, hoarseness, periodic loss of consciousness etc.) which does not correlate with the events described by the evangelists. Besides even at assumption about accumulation of the serous fluid in the pericardium cavity its volume hardly would exceed $150-200 \mathrm{ml}$ even at superacute development of the hydropericardium [22].

In case of spearing of the pericardium at the vertical position of the crucified body the most quantity of the pericardial exudate would remain in the anterioinferior pericardium sinus which is between it's sternocostal and diaphragmatic departments. A fluid flowed out the pericardium cavity would partially be absorbed by mediastinal fat, partially would mix up with blood and would not be visible at the external bleeding. In search of an explanation of Jesus Christ death at the crucifixion Frederick $\mathrm{T}$ Zugibe, the former chief medical examiner of the Rockland County (NY, USA), has conducted a series of experiments with suspension of healthy volunteers on a cross [23]. During the experiments outstretched arms of the volunteers were fixed by soft leather gloves to a horizontal beam of the cross and the legs semibent in the knee joints were fixed with the soles faced to the vertical beam. Monitoring of cardiovascular and respiratory 
activity was carried out through the experiment. Generally the study was stopped at 40-60 min after occurrence of the pain in extremities and considerable physical discomfort. Relying on the data received F.T Zugibe has concluded that the crucified person do not suffer from significant breathing and cardiac disturbances which could lead to death. Having subjected to criticism P. Barbet's theory of progressing asphyxia as a cause of death at the crucifixion, F.T Zugibe came to conclusion that the death in this cases was caused by hypovolemic shock developed in consequence of circumstances of execution: castigation with massive damage of soft tissues of the back, blood loss and dehydration [23].

The conclusions have caused objections of many researchers. Thus for example it is underlined that F.T Zugibe hasn't considered the data of K-S.D. Schulte who has noticed that if the crucified can lean against feet even periodically (once within 20 seconds) it normalize cardiovascular activity and breathing [9]. Obviously, at the experiment when a crucified person may lean against the semibent legs the respiratory failure will be developed rather slowly. Certainly, now any researcher will not venture a fully reproducing of the original historical circumstances of the execution, and humane conditions of the performed experiments significantly reduce their value. Thereby data of so short experiment are out of line with the real historical events when executed people were staying on the crosses even more than one day. In addition, hypovolemicshock has the stages with their own clinical signs followed by change of consciousness. Thus the first (erectile) phase of the shock lasts several minutes and is characterized by motor and talkative excitation, tachycardia, breathing enhancement. The second (torpid) phase of the shock is marked with slackness, hypodynamia, prostration [24]. However there are no data in the Gospel which could testify to any similar change of the Christ's consciousness. All His speeches told on the cross as well as behavior are completely intelligent. Besides the postural asphyxia as cause of death at the crucifixion F.T Zugibe faced sharp criticism the version of P. Barbet about the site of driving the nails into hands of the executed.

However all his objections, in contrast to the position of $\mathrm{P}$. Barbet, are not based on experimental or estimated data but on subjective interpretation of the Turin Shroud materials. W.D. Edwards et al. (1986) have come to conclusion that "The actual cause of Jesus' death, like that of other crucified victims, may have been multifactorial and related primarily to hypovolemic shock, exhaustion asphyxia, and perhaps acute heart failure" [25]. The researchers have assumed that in the circumstances of progressing hypovolemia accompanied with hypoxemia friable blood clots might be formed on the aortic or mitral valve shutters. Being tore of they could lead to acute transmural myocardial infarction which has caused cardiac arrest. Just at the first consideration of the offered version it is visible that it is not original and combines the majority of the previously offered theories with their merits and demerits. Integrative theory of Jesus Christ death was put forward by researchers from Republic of South Africa F.P. Retief and L. Cilliers [26]. Having considered available data concerning history and pathogenetic aspects of the crucifixion, they have come out with the assumption that the death has been caused by progressing hypoxia, hypovolemic shock and vasovagal reflex. The liquid noted by Evangelist John, authors thought, was nothing more than pericardial or pleural effusion [4,5]. Having critically considered a number of theories of Jesus Christ death, M.W. Maslen and P.D. Mitchell [6] have come to the skeptical conclusion that now there are no medical versions which could explain death of the Christ adequately. Authors have assumed the situation can be resolved only with the advent of new archaeological or written evidences [27].

From our point of view the most probable version of the occurred letal outcome is multiple organ failure as a complication of the disseminated intravascular coagulation (DIC). The DIC is the acquired pathology of the coagulation system and is characterized by impairment of the microcirculation in the vital organs (liver, kidneys, adrenal glands, lungs, etc.). Developing in many cases of acute conditions including traumas the DIC can progress within several hours and cause extremely high lethality. The DIC includes several stages each of which is characterised not only specific disturbance of haemocoagulation and clinical picture but also can lead to death. According to different authors DIC numbers from two to six stages, basically on account of the division of the hypocoagulation phase. However for practical use simplified division is more convenient. It assumes two stages: hypercoagulation and hypocoagulation [28]. The first stage of the DIC, hypercoagulation, is characterized by activation of plasma coagulation factors, intravascular thrombocyte and and other blood corpuscles aggregation. It leads to blockade of the vascular bed by fibrin and cell aggregates. The hypercoagulation phase often has very rapid development with fast and considerable activation of blood coagulation. The more powerful the damaging factor the faster progression is. The second stage of the DIC, hypocoagulation, replaces a phase of hypercoagulation and is caused by considerable consumption of the fibrinogen, factors XIII, V, VIII and others procoagulants, and platelets.

Simultaneously pathological inhibitors of blood coagulation are accumulates in the blood, particularly fibrin and fibrinogen degradation products which increase anticoagulant activity of the blood. Any trauma with blood loss is accompanied by coagulation activation. If arterial pressure falls and microcirculation is decelerated in this situation hypercoagulation phase of the DIC may com. This is frequently observed in cases of extensive damage of tissues [29]. These conditions were observed at Jesus Christ crucifixion. The castigation with massive destruction of soft tissues of the back, cross procession, crucifixion and hanging on the cross were well to development of the metabolic acidosis and activation of blood coagulation by the external and internal way of prothrombinase (thromboplastin) formation. The soft tissues of the back damaged at castigation were subjected for additional alteration by hitting against the cross. This promoted ingress of injured tissue fragments in to the circulation and 
releasing of the tissue thromboplastin from the endothelium which initiated hypercoagulation phase of the DIC [30]. It should be noted that the rate of coagulation in the first phase of the DIC may be so high that it is impossible to fill a syringe with blood because of fast clot formation and effluent blood gathers on the surface in the form of the red clots surrounded by semitranslucent yellowish limbus of the liquid lymph [31]. External manifestations of the hypercoagulation phase of the DIC are very modest: the consciousness is clear, patient answers for the questions curtly, organ pathology does not revealed.

The death in case of the DIC may be caused both by acute multiple organ failure and by thromboembolism of the vital organs by emerging blood clots. If a lethal outcome occurs in this phase of the DIC, intravascular separation of blood for the liquid part (lymph) and the friable cellular rest is quite often revealed. If there are wounds on the dead body, effused blood flowing down on the skin as on the dividing surface is being stratified on two streams, almost transparent watery lymph and cellular deposit of red color. Probably it is the specified circumstance that has been noted by a man having stood beside the cross when the Jesus Christ body was speared by the Roman soldier. It should be noted that antiquity doctors understood significance of the state of blood for the human organism. Thus Aristotle had linked the general motor activity of the person with blood in the IV century BC. Aristotle considered blood as the material medium of all soul functions. Having considering such qualities of blood as a sedimentation rate, density and warmth, he defined two components in blood - watery and fibrous. Ancient doctors believed that development of specific disease depends on a ratio of this components, and blood disintegration on the constituent elements was considered as a sign accompanying death. Both ancient Greeks and Romans named a liquid part of the blood as well as all transparent fluids of the organism (for example pericardial fluid) a water [32,33].

However of the total number of synonyms used for denotation of water both as a part of blood and flowing in the organism Romans used word lympha, and Greeks used word $v \delta \omega \rho$ (hydōr). The tradition has continued to this day. Physicians and biologists of all countries still name a liquid part of blood a lymph, and for denotation of accumulation liquids in the cavities of a body they use a root $v \delta \omega \rho$ (hydōr). For example, the

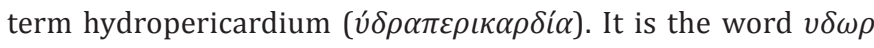
that from all possible Greek synonyms St. John the Theologian chooses for denotation of the blood and water effused from the

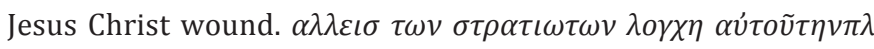

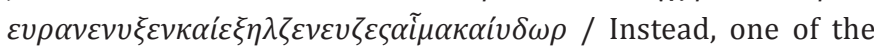
soldiers pierced Jesus' side with a spear, bringing a sudden flow of blood and water (John 19:34). It might be supposed that St. John the Theologian noting effusion the blood and water from the wound stabbed with spear to dead Jesus Christ not only pointed the sacral, religious-mystical meaning of the event, but using from all number of synonyms a word $v \delta \omega \rho$ he emphasizes postmortem character and irreversibility of the event. His words indicate this indirectly «The man who saw it has given testimony, and his testimony is true. He knows that he tells the truth, and he testifies so that you also may believe» (John 19:35).

\section{Conclusion}

Summarizing the above-stated, it is possible to assume quite proved that Jesus Christ death has come as a result of DIC, most likely in the hypercoagulation phase. The circumstances which have caused the pathological condition were castigation with extensive damage of the back soft tissues and their further injury during bearing the Cross and during stay on it at the crucifixion. The additional conditions promoting the DIC were progressive hypoxia caused by the labored breathing, hypovolemia progressing through blood loss and dehydration, unnatural position of the body on the cross, pain from the nailed extremities and strong psycho-emotional shock. This suggestion corresponds with Evangelical texts most exactly and in our opinion can serve for an adequate estimation of the events occurring during the crucifixion. On the basis of the presented stands it is necessary to note that the events accompanying the crucifixion are described in the Gospel with probative medical accuracy and extremely convincingly tell about Jesus Christ physical sufferings and fortitude.

\section{References}

1. Brenner B (2005) Did Jesus Christ die of pulmonary embolism? J Thromb Haemost 3(9): 2130-2131.

2. Bucklin R (1970) The legal and medical aspects of the trial and death of Christ. Med Sci Law 10(1): 14-26.

3. LeBec AA (1925) Physiological Study of the Passion of Our Lord Jesus Chris. The Catholic Medical Guardian, Vol.3 pp.126-136.

4. Schulte KS (1963) Der Tod Jesu in der Sicht der moderner Medizin. Berliner Medizin 7: S177-S186.

5. Sealove BA, Tiyyagura S, Fuster VJ (2008) Takotsubo cardiomyopathy. Gen Intern Med 23(11): 1904-1908.

6. Maslen MW, Mitchell PD (2006) Medical theories on the cause of death in crucifixion. J R Soc Med 99(4): 185-188.

7. Davis CT (1965) The Crucifixion of Jesus: The Passion of Christ from a Medical Point of View. Ariz Med 22: 183-187.

8. Pfeiffer CF, Vos HF, Rea J (1975) Wycliffe Bible Encyclopedia. Moody Press, USA, pp. 149-152.

9. Shvets NI, Bentsa TM, Fogel EA (2006) Hypovolemic shock: clinic, diagnosis, ugrent measures. Med of emergency conditions 6(7): 88-92.

10. FP Retief, L Cilliers (2006) Christ's crucifixion as a medico-historical event. Acta Theologica 26(2): 294-310.

11. Wijffels F (2000) Death on the cross:did the Turin Shroud once envelop a crucified body? Br Soc Turin Shroud 52(3): 23-37.

12. Depasquale NP, Burch GE (1963) Burch GE: Death by crucifixion. Am Heart J 66: 434-435.

13. Marchukova S (2003) Medicinein mirrov of history. Publishing Europe House, Europe, pp.272.

14. John Wilkinson (1975) The Incident of the Blood and Water in John 19.34. Scottish Journal of Theology 28(2): 149-172.

15. Thomas G DeLoughery (2010) Disseminated Intravascular Coagulation. Hematology 5(1): 39-42. 
16. Edwards WD, Gabel WJ, Hosmer FE (1986) On the Physical Death of Jesus Christ. JAMA 255(11): 1455-1463.

17. Johnson CD (1978) Medical and Cardiological Aspects of the Passion and Crucifixion of Jesus, the Christ. Bol Asoc Med P Rico 70(3): 97-102.

18. Zerbino DD, LukasievichLL (1989) Dissiminated intravascular coagulation. M Medicine pp. 256.

19. Vorob'ev AI, Gorodetskiı̌ VM, Vasil'ev SA, Panchenkov NR, Fomin MD (1999) Acute massive blood loss and dissiminated intravascular coagulation. Ter Arkh 71(7): 5-12.

20. Retief FP, Cilliers L (2003) The history and pathology of crucifixion. S Afr Med J 93(12): 938-941.

21. Stevenson WG, Linssen GC, Havenith MG, Brugada P, Wellens HJ (1989) The spectrum of death after myocardial infarction:a necropsy study. Am Heart J 118(6): 1182-1188.

22. Abakoumov MM, Danielian ShN, Radchenko YA (2010) Prevention and treatment of post-traumatic pericarditis. Surgery MNI Pirogov4: 1620.

23. Zugibe F (2005) The Crucifixion of Jesus: A Forensic Inquiry. M Evans Publishers, USA, pp.384.

24. Bergsma S (1948) Did Jesus Die of a Broken Heart? The Calvin Forum 14: 165
25. Lumpkin R (1978) The Physical Suffering of Christ. J Med Assoc State Ala 47(9): 8-10

26. Primrose R (1949) A surgeon looks at the crucifixion. Hibbert J 47: 382-388.

27. FP Retief, L Cilliers (2006) Christ's crucifixion as a medico-historical event. Acta Theologica 26(2): 294-310.

28. Barbet P (1953) A Doctor at Calvary: The Passion of Our Lord Jesus Christ as Described by a Surgeon. Earl of Wicklow, USA, pp.12-18,37$147,159-175,187-208$.

29. Barbet $P$ (1937) Les Cinq Plaies du Christ ( $2^{\text {nd }}$ edn). Procure du Carmel de l'Action de Graces, Paris.

30. Omerovic E (2009) Did Jesus die of a 'broken heart'? Europ J Heart Failure 11(8): 729-731.

31. Levi M, Hugo ten Cate (1999) Disseminated Intravascular Coagulation. N Engl J Med 341: 586-592.

32. Aristotle (1937) About the parts of animals. Trans VP Karpov, M Biomedgiz pp.220.

33. Belviso M, De Donno A, Vitale L, Introna F (2003) Positional Asphyxia: eflection on 2 cases. Am J Forensic Med Pathol 24(3): 292-297.

\section{Your next submission with Juniper Publishers} will reach you the below assets

- Quality Editorial service

- Swift Peer Review

- Reprints availability

- E-prints Service

- Manuscript Podcast for convenient understanding

- Global attainment for your research

- Manuscript accessibility in different formats

( Pdf, E-pub, Full Text, Audio)

- Unceasing customer service

Track the below URL for one-step submission https://juniperpublishers.com/online-submission.php 